\title{
Non-Alcoholic Fatty Liver Disease is Associated with an Increased Mortality in Adult Patients with Group B Streptococcus Invasive Disease
}

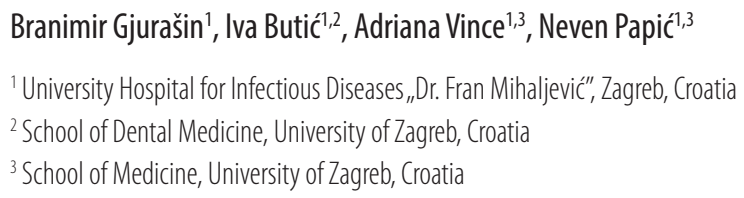

Nealkoholna masna bolest jetre povezana je s većom smrtnošću kod odraslih bolesnika s invazivnom bolešću uzrokovanom streptokokom grupe B

Keywords:

Non-alcoholic fatty liver disease (NAFLD) Group B Streptococcus sepsis

\section{Ključne riječi:}

nealkoholna masna bolest jetre beta-hemolitǐki streptokok grupe B sepsa

Primljeno: 07-10-2020

Received: 07-10-2020

Prihvaćeno: 01-12-2020 Accepted: 01-12-2020

$\square$ Corresponding author:

Neven Papić, MD, PhD, Viral Hepatitis Department, University Hospital for Infectious Diseases, „Dr. Fran Mihaljevic", Mirogojska 8, 10000 Zagreb; e-mail: npapic@bfm.hr

\section{Summary}

Background: Group B Streptococcus (GBS) is a significant cause of invasive disease among adult non-pregnant patients with increasing incidence and mortality rates. Although non-alcoholic fatty liver disease (NAFLD) is associated with components of metabolic syndrome previously recognized as risk factors for GBS, the impact of NAFLD on GBS course and outcomes is unknown.

Methods: We conducted a retrospective cohort study of all non-pregnant adult patients diagnosed with invasive GBS infection during a 15-year period.

Results: 102 patients were included in the study (46.1\% males; median age 69, IQR 58-78 years). Disease primarily presented as bacteremia without a defined source $(37 ; 36.3 \%)$, cellulitis/erysipelas $(35 ; 34.3 \%)$, pneumonia (13; $12.7 \%)$ and endocarditis $(8 ; 7.8 \%)$. The most common comorbidities were diabetes $(42 ; 41.2 \%)$, dyslipidemia (39; $38.2 \%)$, cardiovascular disease $(34 ; 33.3 \%)$, peripheral vascular disease $(21 ; 20.6 \%)$, obesity $(21 ; 20.6 \%)$ and malignancy (10;9.8\%). Based upon the results of abdominal ultrasound, the patients were divided into two groups: the ones with steatosis (44; $43.1 \%)$ and the ones without steatosis (58; 56.9\%). There were no significant differences in clinical presentations and comorbidities between groups. In-hospital mortality was $29.5 \%(13 / 44)$ in patients with NAFLD and 10.3\% (6/58) in the control group ( $p=0.0200)$. Endocarditis (OR 6.69; 95\%Cl 1.045-44.46, $p=0.0410)$, acute renal failure (OR 13.92; 95\% Cl 3.00-77.71, $p=0.0013)$, qSOFA > 2 (OR 23.93; 95\%Cl 4.66-171.2) and NAFLD (OR 6.64; 95\% Cl 1.23-47.88, p=0.0258) were independently associated with in-hospital mortality.

Conclusions: NAFLD is associated with higher mortality in patients suffering from invasive GBS disease which appears to be independent of other components of the metabolic syndrome, such as obesity and diabetes mellitus.

Sažetak

Uvod: Streptokok grupe B (GBS) značajan je uzrok invazivne bolesti kod odraslih bolesnika s porastom incidencije i smrtnosti. lako je nealkoholna masna bolest jetre - NAFLD (engl. non-alcoholic fatty liver disease) povezana s komponentama metaboličkog sindroma koji su prepoznati kao čimbenici rizika za GBS, utjecaj NAFLD na tijek i ishode invazivne GBS bolesti još uvijek nije poznat.

Metode: Proveli smo retrospektivno kohortno istraživanje svih odraslih bolesnika koji nisu trudni, a kojima je dijagnosticirana invazivna GBS infekcija tijekom 15-godišnjeg razdoblja.

Rezultati: U istraživanje je uključeno 102 bolesnika (46,1\% muškaraca; srednja dob 69, IQR 58-78 godina). Bolest se primarno prezentirala kao bakterijemija nepoznatog ishodišta (37; 36,3\%), celulitis/erizipel (35; 34,3\%), pneumonija (13; 12,7\%) i endokarditis (8; 7,8\%). Najčěčí komorbiditeti bili su dijabetes (42; 41,2\%), dislipidemija (39; 38,2\%), kardiovaskularne bolesti (34; 33,3\%), periferne vaskularne bolesti $(21 ; 20,6 \%)$, pretilost (21; 20,6\%) i maligna bolest (10; 9,8\%). Prema nalazu ultrazvuka abdomena, bolesnici su podijeljeni u dvije skupine: bolesnici s NAFLD $(44 ; 43,1 \%)$ i bolesnici bez steatoze jetre $(58 ; 56,9 \%)$. Nije bilo značajnih razlika u kliničkoj prezentaciji i komorbiditetima među skupinama. Smrtnost za vrijeme hospitalizacije iznosila je 29,5\% (13/44) kod bolesnika s NAFLD i 10,3\% (6/58) u kontrolnoj skupini ( $p=0,0200)$. Endokarditis (OR 6,69; 95\% Cl 1,045$44,46, p=0,0410)$, akutno zatajenje bubrega (OR 13,92; 95\% Cl 3,00-77,71, $p=0,0013)$, qSOFA > 2 (OR 23,93; 95\% Cl 4,66-171,2) i NAFLD (OR 6,64; 95\% Cl 1,23-47,88, p = 0,0258) bili su neovisno povezani sa smrtnošću. Zaključci: NAFLD je povezan s većom smrtnošću kod bolesnika s invazivnom GBS bolešću i čini se da je to neovisno 0 drugim komponentama metaboličkog sindroma, kao što su pretilost i dijabetes melitus. 


\section{Introduction}

Non-alcoholic fatty liver disease (NAFLD) and its role in bacterial infections have only recently begun to be revealed. NAFLD represents a spectrum of chronic liver diseases ranging from simple steatosis to non-alcoholic steatohepatitis (NASH), cirrhosis, and hepatocellular carcinoma ${ }^{[1]}$. NAFLD is associated with the components of metabolic syndrome, primarily diabetes mellitus and obesity ${ }^{[1]}$. There are cumulative data that NAFLD is associated with systemic changes in the immune response that might have profound effect on infection course and outcome $\mathrm{e}^{[2]}$.

The liver dysfunction in sepsis in patients without pre-existing liver disease is an independent predictor of mortality ${ }^{[3]}$. The risk of developing bacterial infections is even more increased in patients suffering from liver cirrhosis, making them ten times more susceptible to bloodstream infections resulting in a fourfold increase in mortality ${ }^{[4]}$. There are only several clinical studies that examined the role of NAFLD in bacterial infections. NAFLD was associated with an increase in all-cause mortality in patients suffering from community-acquired pneumonia ${ }^{[5]}$. Bacteraemia of gastrointestinal origin and recurrent urinary tract infections were more common in patients with NAFLD ${ }^{[6,7]}$. More recently, NAFLD was identified as a risk factor for Clostridioides difficile infection ${ }^{[8]}$.

However, to the best of our knowledge, there are no data on the association of group B Streptococcus (GBS) diseases in patients with NAFLD. Group B Streptococcus is a significant cause of invasive disease among adult non-pregnant patients with increasing incidence and high mortality rates ${ }^{[9]}$. This is highlighted in the large USA surveillance study, where the incidence of invasive GBS disease among non-pregnant adults tripled in the last 25 years and in 2016 was higher than the rate of invasive pneumococcal disease in adults ${ }^{[9]}$.

GBS is a pathobiont that is often part of the normal microbiota of the human gastrointestinal tract and rarely causes invasive disease. There is a plethora of studies which attempted to characterize the adults most susceptible to invasive GBS infection. While obesity and diabetes are most common underlying conditions associated with substantially increased risk of infection and mortality ${ }^{[10-12]}$, the role of NAFLD with GBS invasive disease outcomes has not been investigated.

\section{Methods}

\section{Study Design and Patients}

This was a retrospective cohort study conducted at the University Hospital for Infectious Diseases „Dr. Fran Mihaljević" in Zagreb, Croatia (UHID), which also serves as the national referral centre for infectious diseases. We reviewed the hospital records of all consecutive non-pregnant adult patients diagnosed with invasive GBS infection (GBS isolated from normally sterile site) hospitalized in a 15 -year period (20052019). Of the 139 patients suffering from invasive GBS during the period studied, 102 met inclusion criteria and were included in the study $(47,46.1 \%$ males; median age 69, IQR 58-78 years).

\section{Data Collection, Outcomes, and Definitions}

Demographic data, comorbidities (measured by age adjusted for Charlson Comorbidity Index, CCI), the presenting infectious syndrome, antimicrobial therapy, treatment duration, length of hospital stay, complications and outcomes were collected from the patients' charts.

The following blood laboratory data from the admission were analysed: C-reactive protein level (CRP), white blood cell count (WBC), platelet count (Plt), coagulation parameters, aspartate aminotransferase (AST), alanine aminotransferase (ALT), blood urea nitrogen (BUN), serum creatinine and serum albumin concentration. APRI and FIB-4 score were calculated for all patients and were used as a surrogate marker of liver injury ${ }^{[13,14]}$.

Diagnosis of NAFLD was based on the presence of fatty liver by ultrasonography (US) and by the absence of secondary cause of liver steatosis (e.g. chronic viral hepatitis, Wilson's disease, autoimmune hepatitis, alcohol intake $)^{[1]}$. The study protocol conforms to the ethical guidelines of the 1975 Declaration of Helsinki (6th revision, 2008) as reflected in a priori approval by the institution's human research committee.

\section{Statistical Analysis}

The demographic, clinical characteristics, and laboratory data were evaluated and presented descriptively. Fisher's exact test and the Mann-Whitney U test were used to compare the groups, as appropriate. All tests were two-tailed; $\mathrm{p}<0.05$ was considered statistically significant. Binary logistic regression analysis was used to assess the independent predictors of in-hospital mortality. All variables were entered in a backward stepwise logistic regression model. Statistically non-significant predictors were progressively excluded based on a likelihood ratio test. The strength of association was expressed as odds ratio (OR) and its corresponding $95 \%$ confidence intervals (95\% CI). Statistical analyses were performed using the MedCalc for Windows, ver. 19.0.7 (MedCalc Software, Mariakerke, Belgium). 
Results

Disease primarily presented as bacteraemia without a defined source $(37 ; 36.3 \%)$, cellulitis/erysipelas $(35 ; 34.3 \%)$, pneumonia $(13 ; 12.7 \%)$ and endocarditis $(8 ; 7.8 \%)$. The most common comorbidities were diabetes $(42 ; 41.2 \%)$, dyslipidaemia $(39 ; 38.2 \%)$, cardiovascular disease $(34 ; 33.3 \%)$, peripheral vascular disease $(21$; $20.6 \%)$, obesity $(21 ; 20.6 \%)$ and malignancy $(10 ; 9.8 \%)$. Based upon the results of abdominal US the patients were divided into two groups: with steatosis $(44 ; 43.1 \%)$ and without steatosis $(58 ; 56.9 \%)$. There were no significant differences in clinical presentations and comorbidities between groups, as presented in Table 1 .

On admission, the majority of patients had a qSOFA score of 0 or $1(83 ; 81.4 \%)$, even though 80 patients (78.4\%) had $\geq 2$ SIRS criteria; all patients had elevated CRP (median of $111 \mathrm{mg} / \mathrm{L}, \mathrm{IQR} 32-170$ ). Patients with NAFLD were younger (65, IQR 58-73 vs. 75, IQR 6282 years, $\mathrm{p}=0.01$ ), had higher AST (45.0; IQR 30-71 vs. 28.5; IQR 20-71, $\mathrm{p}=0.047)$ and ALT (38; 25.5-55.5 vs. $21.5 ; 14-40, \mathrm{p}=0.009)$ than non-NAFLD group. There were no significant differences in other laboratory results on admission (CRP, BUN, creatinine, haemoglobin, leukocytes, Plt and coagulation).

Fibrosis index-4 (FIB-4) was calculated on blood tests on the admission date, and according to FIB-4 values, the NAFLD group was stratified into 3 catego- ries: 10 (22.7\%) with high risk FIB-4 (FIB-4> 3.25), 12 (27.2\%) with intermediate-risk FIB-4 (1.45 <FIB-4 > 3.25 ) and 22 (50\%) with low risk FIB-4 (FIB-4> 1.45). Moreover, the presence of intermediate/high risk FIB4 as well as the presence of liver cirrhosis were not associated with adverse outcomes in the NAFLD cohort.

The median duration of hospitalization was 14 (IQR 11-19) days in NAFLD and 12.5 (IQR 8.75-16.7) in nonNAFLD group $(\mathrm{p}=0.5961)$. Overall, 41 patients $(40.2 \%)$ developed complications during hospitalization and $24(23.5 \%)$ were admitted to the intensive care unit (ICU). Nosocomial infections (12, $27.3 \%$ vs. $6,10.3 \%$; $\mathrm{p}=0.0359)$ and acute renal failure $(9,20.5 \%$ vs. $3,5.2 \%$; $\mathrm{p}=0.0276)$ were more common in the NAFLD group.

In-hospital mortality was $29.5 \%(13 / 44)$ in patients with NAFLD and $10.3 \%(6 / 58)$ in the control group $(\mathrm{p}=0.0200)$. To determine whether NAFLD was independently associated with in-hospital mortality, we performed a multivariate logistic regression analysis. After adjustment for potential cofounders, endocarditis (OR 6.69; 95\% CI 1.045-44.46, p=0.0410), acute renal failure (OR 13.92; 95\%CI 3.00-77.71, $\mathrm{p}=0.0013$ ), qSOFA $\geq 2$ (OR 23.93; 95\%CI 4.66-171.2) and NAFLD (OR 6.64; 95\%CI 1.23-47.88, $\mathrm{p}=0.0258$ ) were independently associated with in-hospital mortality. Interestingly, diabetes mellitus and obesity were not associated with mortality in our model.

Table 1. Clinical characteristics of patients with invasive Group B streptococcus disease

TABLICA 1. KLINIČKE KARAKTERISTIKE BOLESNIKA OBOLJELIH OD INVAZIVNE BOLESTI UZROKOVANE STREPTOKOKOM GRUPE B

\begin{tabular}{|l|l|l|l|}
\hline & $\begin{array}{l}\text { Liver steatosis } \\
(\mathbf{n = 4 4 )}\end{array}$ & $\begin{array}{l}\text { No liver steatosis } \\
(\mathbf{n = 5 8})\end{array}$ & P-value $^{\mathbf{a}}$ \\
\hline Male sex & $24(54.5 \%)$ & $23(39.7 \%)$ & 0.1625 \\
\hline Age, year (median, IQR $)$ & $65(58-73)$ & $75(62-82)$ & 0.0127 \\
\hline Long-term facility resident & $4(9.1 \%)$ & $7(12.1 \%)$ & 0.7533 \\
\hline Comorbidities & & $19(32.8 \%)$ & 0.0672 \\
\hline Diabetes mellitus & $23(52.3 \%)$ & $18(31.0 \%)$ & 0.1022 \\
\hline Dyslipidaemia & $21(47.7 \%)$ & $16(27.6 \%)$ & 0.2039 \\
\hline Cardiovascular disease & $18(40.9 \%)$ & $9(15.5 \%)$ & 0.2159 \\
\hline Peripheral vascular disease & $12(27.3 \%)$ & $8(13.8 \%)$ & 0.0820 \\
\hline Obesity & $13(29.5 \%)$ & $10(17.2 \%)$ & 0.7849 \\
\hline Malignancy & $6(13.6 \%)$ & $5(8.6 \%)$ & 0.7420 \\
\hline Chronic renal disease & $5(11.4 \%)$ & $5(8.6 \%)$ & 1.0000 \\
\hline COPD/asthma & $4(9.1 \%)$ & $9(15.5 \%)$ & 0.3145 \\
\hline Neurological diseases & $11(25.0 \%)$ & $20(34.5 \%)$ & 0.6829 \\
\hline Clinical syndrome & & $20(34.5 \%)$ & 1.0000 \\
\hline Primary bacteraemia without a defined source & $17(38.6 \%)$ & $15(34.1 \%)$ & \\
\hline Skin infection & & \\
\hline
\end{tabular}




\begin{tabular}{|l|l|l|l|}
\hline Pneumonia & $5(11.4 \%)$ & $8(13.8 \%)$ & 0.7731 \\
\hline Endocarditis & $3(6.8 \%)$ & $5(8.6 \%)$ & 1.0000 \\
\hline Osteoarticular infection & $2(4.5 \%)$ & $2(3.4 \%)$ & 1.0000 \\
\hline Urinary tract infection & $1(2.3 \%)$ & $2(3.4 \%)$ & 1.0000 \\
\hline CNS infection (meningitis) & $1(2.3 \%)$ & $1(1.7 \%)$ & 1.0000 \\
\hline Clinical Course and Outcomes & & & 0.5961 \\
\hline Duration of hospitalization & $14(11-19)$ & $12,5(8,75-16,7)$ & 0.0200 \\
\hline In-hospital mortality & $13(29.5 \%)$ & $6(10.3 \%)$ & 0.1024 \\
\hline ICU admission & $14(31.8 \%)$ & $10(17.2 \%)$ & 0.0820 \\
\hline Mechanical ventilation & $13(29.5 \%)$ & $8(13.8 \%)$ & 0.0359 \\
\hline Nosocomial infection & $12(27.3 \%)$ & $6(10.3 \%)$ & 0.0276 \\
\hline Acute renal failure & $9(20.5 \%)$ & $3(5.2 \%)$ & 0.1198 \\
\hline Heart failure & $8(18.2 \%)$ & $4(6.9 \%)$ & 0.5779 \\
\hline Other & $7(15.9 \%)$ & $7(12.1 \%)$ & \\
\hline
\end{tabular}

${ }^{\text {a }}$ Fisher exact or Mann-Whitney U test, as appropriate; ${ }^{\mathrm{b}} \mathrm{IQR}$, interquartile range; ${ }^{\mathrm{c}}$ ICU, intensive care unit

\section{Discussion}

The incidence of GBS invasive disease among adult non-pregnant patients has been rising for several decades, and adults now account for nearly $90 \%$ of all invasive GBS diseases ${ }^{[9]}$. The well-defined risk factors for invasive GBS disease include elderly age and components of the metabolic syndrome; obesity and diabetes ${ }^{[10-12]}$. In addition, both diabetes mellitus and obesity were also shown to be independently associated with higher rates of group B streptococcal colonization ${ }^{[15]}$.

We have provided the first evidence that invasive GBS disease in patients with NAFLD is associated with higher mortality than in patients without NAFLD. Moreover, this appears to be independent of other components of metabolic syndrome, such as obesity and diabetes mellitus. Furthermore, nosocomial infections and acute renal failure were more common in the NAFLD group, which highlights the impact of NAFLD on disease outcome. Since a significant proportion of our cohort (43\%) had liver steatosis, NAFLD could be considered as a risk factor for invasive GBS disease.

Patients with NAFLD might be particularly susceptible to severe disease as they carry a particular combination of previously mentioned risk factors. Firstly, the presence of type- 2 diabetes confers susceptibility to infection and incidence of invasive GBS infections is even more increased among patients with poor glycaemic control ${ }^{[10-12]}$. Secondly, considering a high prevalence of cardiovascular disease, patients with NAFLD may show a decreased cardiac reserve that might be associated with increased mortality. Both obesity and diabetes are associated with changes in skin barrier function or alteration of immune function ${ }^{[16]}$.
Notably, no previous study examined the association of NAFLD with GBS. The possible explanation of increased risk of invasive GBS disease and high mortality rates in NAFLD patients may include higher GBS colonization due to the changes in gut microbiome, and the impairment of gut and systemic immune response, the pathophysiology of which is largely under-investigated ${ }^{[2]}$. NAFLD is now considered a multisystem disease with significant impact on the innate and adaptive immune responses. A complex crosstalk between the gut, adipose tissue and the liver, as well as the changes in expression of cytokines, adipokines and cells of the immune system which drives the diseases progression and might have significant impact to the systemic response to infection, sepsis course and outcome. For example, it was shown that patients with NAFLD have higher serum concentrations of common inflammatory biomarkers, such as C-reactive protein (CRP) and interleukins (specifically IL6, IL17, leptins, TNF- $\alpha$ and TGF- $\beta$ ), which correlate with the prognosis of NAFLD ${ }^{[17]}$. Moreover, a recently described highly proinflammatory $\mathrm{Th}-17$ response present in patients with NAFLD might unbalance pro-inflammatory and anti-inflammatory response necessary for bacterial clearance and resolution of inflammation to promote recovery from sepsis ${ }^{[18,19]}$.

The major limitation of this study comes from its retrospective design; the diagnosis of NAFLD was based on abdominal US and patients were not systematically screened for other causes of liver steatosis, except from data available in medical charts. Furthermore, the diagnosis of liver steatosis in our cohort might be underdiagnosed, since smaller percentage 
of obese and diabetics had fatty liver than previously reported in other studies. Further, the number of patients with intermediate/high risk FIB-4 and established NAFLD associated cirrhosis was probably insufficient to draw definitive conclusions. Although the study population was relatively small; we included consecutive patients with imaging of the liver available or known diagnosis of NAFLD, providing a more reliable selection of the study cohort: NAFLD vs nonNAFLD patients.

In conclusion, we provide the first data on invasive GBS course in patients with NAFLD. This might be relevant for identification of adult non-pregnant patients at high risk for invasive GBS disease who might benefit from prophylactic measures. Importantly, the efficacy and immunogenicity of GBS vaccines which are in development for prevention of neonatal disease may be impacted by NAFLD in adult population. In addition, this highlights the need for further prospective studies to evaluate the association of NAFLD with the outcomes of bacterial infections.

Conflict of interest: The authors declare no conflict of interest.

Source of Funding: This publication was in part supported by the Croatian Science Foundation project titled „The role of immune semaphorins in NAFLD and sepsis" (principal investigator Neven Papić, project number UIP-2019-04-7194).

\section{REFERENCES}

${ }^{[1]}$ European Association for the Study of the L, European Association for the Study of D, European Association for the Study of O. EASL-EASD-EASO Clinical Practice Guidelines for the management of non-alcoholic fatty liver disease. J Hepatol. 2016;64(6):1388-402.

${ }^{[2]}$ Petta S, Valenti L, Bugianesi E, et al. A "systems medicine" approach to the study of non-alcoholic fatty liver disease. Dig Liver Dis. 2016;48(3):333-42.

${ }^{[3]}$ Yan J, Li S, Li S. The role of the liver in sepsis. Int Rev Immunol. 2014;33(6):498-510.

${ }^{[4]}$ Wong F, Bernardi M, Balk R, et al. Sepsis in cirrhosis: report on the 7th meeting of the International Ascites Club. Gut. 2005;54(5):718-25.

${ }^{[5]}$ Nseir WB, Mograbi JM, Amara AE, Abu Elheja OH, Mahamid MN. Non-alcoholic fatty liver disease and 30-day all-cause mortality in adult patients with community-acquired pneumonia. QJM. 2019;112(2):95-9.
${ }^{[6]}$ Nseir W, Amara A, Farah R, Ahmad HS, Mograbi J, Mahamid M. Non-alcoholic Fatty Liver Disease is Associated with Recurrent Urinary Tract Infection in Premenopausal Women Independent of Metabolic Syndrome. Isr Med Assoc J. 2019;21(6):386-9.

${ }^{[7]}$ Nseir W, Artul S, Nasrallah N, Mahamid M. The association between primary bacteraemia of presumed gastrointestinal origin and non-alcoholic fatty liver disease. Dig Liver Dis. 2016;48(3):343-4.

${ }^{[8]}$ Papic N, Jelovcic F, Karlovic M, Maric LS, Vince A. Non-alcoholic fatty liver disease as a risk factor for Clostridioides difficile infection. Eur J Clin Microbiol Infect Dis. 2020;39(3):56974.

${ }^{[9]}$ Francois Watkins LK, McGee L, Schrag SJ, et al. Epidemiology of Invasive Group B Streptococcal Infections Among Non-pregnant Adults in the United States, 2008-2016. JAMA Intern Med. 2019;179(4):479-88.

${ }^{[10]}$ Jump RLP, Wilson BM, Baechle D, et al. Risk Factors and Mortality Rates Associated With Invasive Group B Streptococcus Infections Among Patients in the US Veterans Health Administration. JAMA Netw Open. 2019;2(12):e1918324.

${ }^{[11]}$ Pitts SI, Maruthur NM, Langley GE, Pondo T, Shutt KA, Hollick R, et al. Obesity, Diabetes, and the Risk of Invasive Group B Streptococcal Disease in Non-pregnant Adults in the United States. Open Forum Infect Dis. 2018;5(6):ofy030.

${ }^{[12]}$ Park SY, Park Y, Chung JW, et al. Group B streptococcal bacteraemia in non-pregnant adults: results from two Korean centres. Eur J Clin Microbiol Infect Dis. 2014;33(10):1785-90.

${ }^{[13]}$ Loaeza-del-Castillo A, Paz-Pineda F, Oviedo-Cardenas E, Sanchez-Avila F, Vargas-Vorackova F. AST to platelet ratio index (APRI) for the non-invasive evaluation of liver fibrosis. Ann Hepatol. 2008;7(4):350-7,

${ }^{[14]}$ Sumida Y, Yoneda M, Hyogo H, et al. Validation of the FIB4 index in a Japanese non-alcoholic fatty liver disease population. BMC Gastroenterol. 2012;12:2.

${ }^{[15]}$ Ramos E, Gaudier FL, Hearing LR, Del Valle GO, Jenkins S, Briones D. Group B streptococcus colonization in pregnant diabetic women. Obstet Gynecol. 1997;89(2):257-60.

${ }^{[16]}$ Fontana L, Eagon JC, Colonna M, Klein S. Impaired mononuclear cell immune function in extreme obesity is corrected by weight loss. Rejuvenation Res. 2007;10(1):41-6.

${ }^{[17]}$ Paquissi FC. Immune Imbalances in Non-Alcoholic Fatty Liver Disease: From General Biomarkers and Neutrophils to Interleukin-17 Axis Activation and New Therapeutic Targets. Front Immunol. 2016;7:490.

${ }^{[18]}$ Van Herck MA, Weyler J, Kwanten WJ, et al. The Differential Roles of T Cells in Non-alcoholic Fatty Liver Disease and Obesity. Front Immunol. 2019;10:82.

${ }^{[19]}$ Sutti S, Albano E. Adaptive immunity: an emerging player in the progression of NAFLD. Nat Rev Gastroenterol Hepatol. 2020;17(2):81-92. 